\title{
A New Species of Genus Diplastrella (Demospongiae: Hadromerida: Spirastrellidae) from Korea
}

\author{
Mi Jeong Kim and Chung Ja Sim* \\ Department of Biological Sciences, College of Life Sciences and Nano Technology, \\ Hannam University, Daejeon 305-811, Korea
}

\begin{abstract}
A new species Diplastrella yongmeoriensis n. sp. was collected from Jejudo Island, Korea in 2008. This new species is similar to D. bistellata (Schmidt, 1862) in growth form and skeletal structure but differs in the composition and size of spicules. The genus Diplastrella is reported for the first time in Korea.
\end{abstract}

Key words: Diplastrella, Spirastrellidae, Korea

\section{INTRODUCTION}

The family Spirastrellidae Ridley \& Dendy, 1886 (Demospongiae, Hadromerida) is characterized by encrusting growth form and microscleres. The genus Diplastrella consist of diplaster and spiraster as microscleres. Skeleton formed by megascleres in ascending bundle and dense layer of microscleres in the ectosomal region. Two species of this genus Diplastrella have been reported worldwide (Hooper and van Soest, 2002). In the present study, we discorvered this genus for the first time in Korea. The sponge was collected by hand from intertidal zone, tide pool at Yongmeori, Sagyeri, Jejudo Island, Korea. All procedures were followed the methods of Rützler (1978). The materials examined in this study were deposited in the Natural History Museum and Department of Biological Sciences, Hannam University, Daejeon, Korea.

\section{SYSTEMATIC ACCOUNTS}

Phylum Porifera Grant, 1836

Class Demospongiae Sollas, 1885

Order Hadromerida Topsent, 1894

Family Spirastrellidae Ridley \& Dendy, 1886

$1 *$ Diplastrella yongmeoriensis n. sp. (Figs. 1-2)

Material examined. Holotype (Por. 94). Intertidal zone, Tide

*To whom correspondence should be addressed

Tel: 82-42-629-8755, Fax: 82-42-629-8751

E-mail: cjsim@hnu.kr pool, Yongmeori, Sagyeri, Jejudo Island, 5 Aug. 2008, C.J. Sim. Paratype (Por. 94 -1). Intertidal zone, Tide pool, Yongmeori, Sagyeri, Jejudo Island, 15 Oct. 2008, C.J. Sim.

Description. Encrusting growth form, size up to $3 \times 2 \mathrm{~cm}$, $0.2 \mathrm{~cm}$ thick. Texture soft and fragile. Surface smooth and uneven. Oscules $0.5-1 \mathrm{~mm}$ in diameter, open on surface. Colour dark brown in life, beige in alcohol. Ectosomal skeleton crust of small diplasters. Choanosomal skeleton formed by tylostyles in ascending bundle. Basal layer consist of large diplasters and large spirasters. Spicules, megascleres with tylostyle. Tylostyles have circular or oval head outline and taper to a rounded, stepped (rare), or sharp point. Microscleres, diplasters and spirasters, very variable in shape and size.

Spicules.

Megascleres

Tylostyles $240-412 \times 5-12 \mu \mathrm{m}$

Microscleres

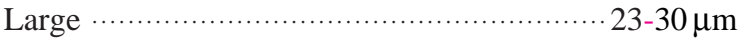

Small diplasters $\ldots \ldots \ldots \ldots \ldots \ldots \ldots \ldots \ldots \ldots \ldots \ldots \ldots, 6-12 \mu \mathrm{m}$

Large spirasters ….......................... 32-35 $\mu \mathrm{m}$

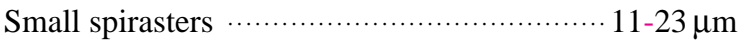

Etymology. This species is named after the type locality, Yongmeori, Jejudo Island, Korea.

Remarks. Diplastrella yongmeoriensis n. sp. is closely related to Diplastrella bistellata (Schmidt, 1862) in growth form and skeleton structure but differs in the composition and size of spicules. Tylostyles of this new species are smaller than the latter. This new species has diplaster and spiraster, but the latter has only diplasters (Table 1).

\footnotetext{
$1 *$ 용머리쌍별해면 (신칭)
} 


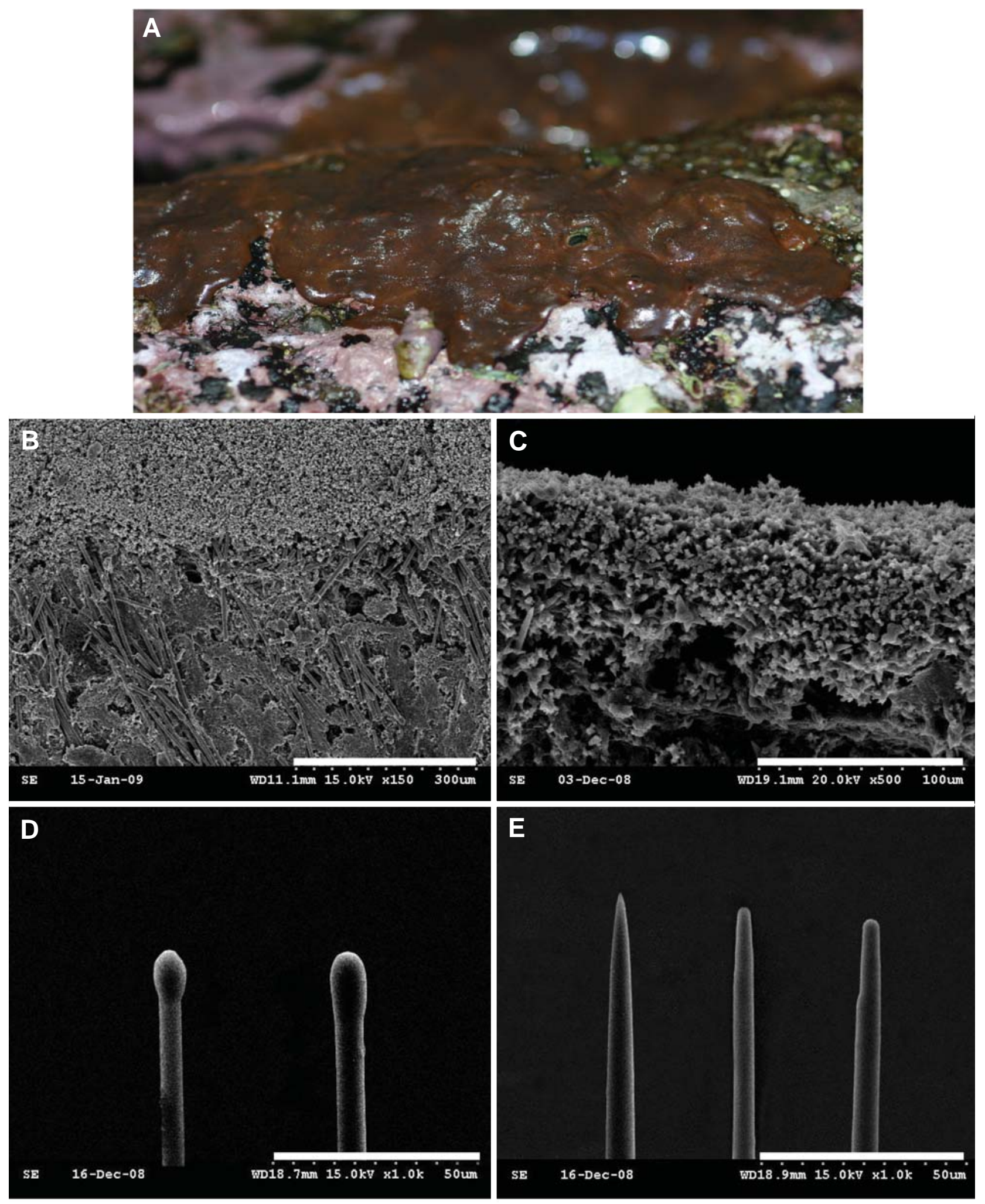

Fig. 1. Diplastrella yongmeoriensis n. sp. A, entire animal; $B$, skeletal structure; $C$, magnification of ectosomal region showing the small diplasters; D, heads of tylostyles; $E$, ends of tylostyles. Scale bars=300 $\mu \mathrm{m}(B), 100 \mu \mathrm{m}(C), 50 \mu \mathrm{m}(D, E)$. 

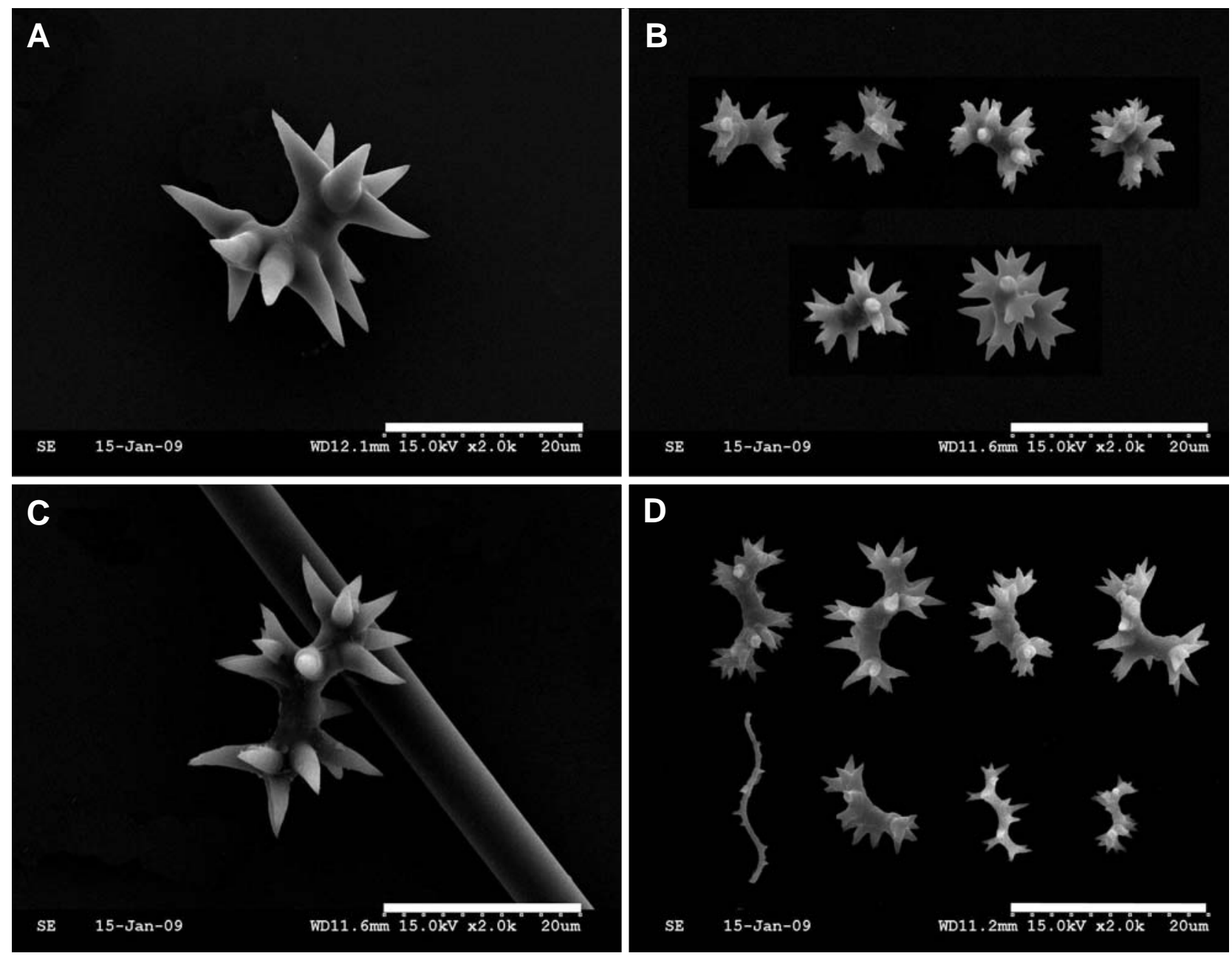

Fig. 2. Diplastrella yongmeoriensis $\mathrm{n}$. sp. A, large diplaster; $B$, small diplasters; C, large spiraster; $D$, small spirasters. Scale bars $=20 \mu \mathrm{m}(A-D)$.

Table 1. The character comparison between $D$. yongmeoriensis n. sp. and D. bistellata

\begin{tabular}{|c|c|c|c|c|}
\hline \multirow[t]{3}{*}{ Characters } & \multicolumn{2}{|c|}{ Species } & \multirow{2}{*}{$\begin{array}{c}\text { D. yongmeorien- } \\
\text { sis } \mathrm{n} . \mathrm{sp} \text {. } \\
\text { Encrusting }\end{array}$} & \multirow{2}{*}{$\begin{array}{l}\text { D. bistellata } \\
\text { Encrusting }\end{array}$} \\
\hline & $\begin{array}{l}\text { Growth } \\
\text { form }\end{array}$ & & & \\
\hline & Colour & & Brown & Red \\
\hline \multirow{3}{*}{$\begin{array}{l}\text { Spicules } \\
(\mu \mathrm{m})\end{array}$} & Tylostyle & & $\begin{array}{c}240-412 \times \\
5-12\end{array}$ & $\begin{array}{c}450-630 \times \\
10-13\end{array}$ \\
\hline & Diplaster & $\begin{array}{l}\text { Large } \\
\text { Small }\end{array}$ & $\begin{array}{r}23-30 \\
6-12\end{array}$ & $\begin{array}{l}25-45 \\
11-20\end{array}$ \\
\hline & Spiraster & $\begin{array}{l}\text { Large } \\
\text { Small }\end{array}$ & $\begin{array}{l}32-35 \\
11-23\end{array}$ & - \\
\hline
\end{tabular}

\section{ACKNOWLEDGEMENTS}

This research was supported by a grant from Marine Bio- technology Programme funded by Ministry of Land, Transport and Maritime Affairs of Korean Government.

\section{REFERENCES}

Hechtel, G.J., 1965. A systematic study of the Demospongiae of Port Royal, Jamaica. Bull. Peabody Mus. of Nat. Hist., 20: 1-103.

Hooper, J.N.A. and W.M. van Soest, 2002. Systema Porifera : A guide to the classification of sponges. Kluwer Academic/ Plenum Publishers Press, USA, pp. 1-1101.

Rho, B.J. and C.J. Sim, 1976. On the classification distribution of the marine benthic animals in Korea. 4. Sponges. J. Korean Res. Inst. Better Liv., Ewha Womans Univ., 16: 67 -87 .

Rützler, K. and M. Sarà, 1962. Diplastrella ornata, eine neue mediterrane Art der Familie Spirastrellidae (Demospong- 
Mi Jeong Kim and Chung Ja Sim

iae). Zool. Anz., 169(5-6): 231-236.

Rützler, K., 1978. Sponges in coral reefs. In Stoddart, D.R. and R.E. Johannes, eds., Coral Reefs: Research Methods. Monogr. Oceanogr. Neth. UNESCO, 5: 299-313.

Sim, C.J. and H.S. Byeon, 1991. A systematic study on the ma- rine sponges from South Sea of Korea-Three new record for Korea-. Korean J. Syst. Zool., 7(1): 111-116.

Received February 9, 2009 Accepted March 9, 2009 